Ks. Adam TONDERA

(Katowice, UŚ)

\title{
ZWIĄZEK MIĘDZY CHRYSTOLOGIĄ A TEORIĄ PRAW NATURY W TRAKTACIE EUZEBIUSZA Z CEZAREI PRZECIWKO HIEROKLESOWI
}

Na okoliczności powstania i na problematykę apologetycznego traktatu Euzebiusza, który zwykle tytułowany jest w skrócie: Przeciwko Hieroklesowi (Contra Hieroclem), wskazuje wyraźniej jego pełny tytuł w manuskryptach: Przeciwko dzietu Filostrata o Apoloniuszu z Tiany z powodu porównania go

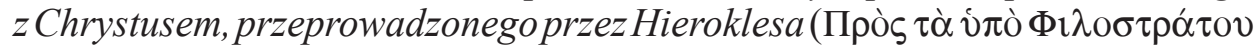

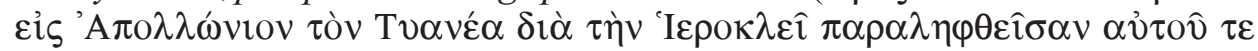

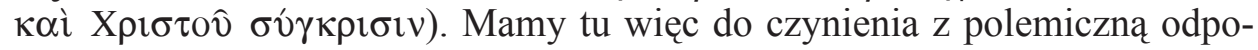
wiedzią na antychrześcijańskie pismo Sossianusa Hieroklesa, opublikowane w 303 r., w którym ten wysoki urzędnik cesarza Dioklecjana i prześladowca chrześcijan dokonał przeciwstawienia Apoloniusza Chrystusowi. Niezachowany do naszych czasów traktat Hieroklesa pod tytułem: Przyjaciel prawdy

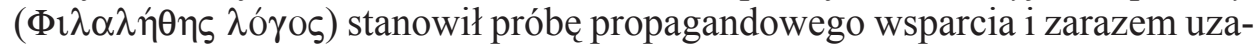
sadnienia srogich praktyk prześladowczych, których dopuszczał się sam autor najpierw jako namiestnik Bitynii, a później jako prefekt Egiptu.

W prezentowaniu pogańskiego konkurenta Chrystusa posłużył się on $\dot{Z} y$ -

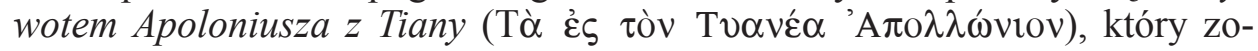
stał napisany prawie sto lat wcześniej przez Flawiusza Filostrata, wybitnego przedstawiciela kulturowego prądu ,drugiej sofistyki”. Tytułowy bohater dzieła Filostrata, wędrowny mędrzec i zwolennik pitagoreizmu z I wieku, ukazany

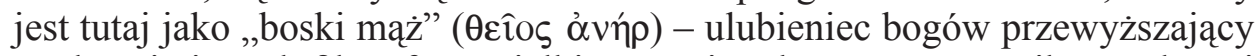
mądrością innych filozofów, wielki asceta i cudotwórca, strażnik moralności i tradycyjnej religii grecko-rzymskiej, który po licznych podróżach i bogatej działalności odchodzi z tego świata, wstępując prosto do nieba.

W swoim apologetycznym traktacie, powstałym prawdopodobnie około roku 312, Euzebiusz postanowił przeanalizować Żywot Apoloniusza z Tiany, aby poddać systematycznej krytyce wizerunek „boskiego męża”, który został nakreślony przez Filostrata, a następnie wykorzystany przez Hieroklesa w polemice antychrześcijańskiej ${ }^{1}$.

${ }^{1} \mathrm{Na}$ temat polemiki, powstałej wokół postaci Apoloniusza z Tiany, por. M. Dzielska, Apolloniusz z Tiany. Legenda i rzeczywistość, Kraków 1983, 115-137; taż, Przedmowa, w: Flawiusz 
1. Prawa natury. Filozoficzno-teologiczny aspekt tej krytyki dotyczy przede wszystkim samej koncepcji prezentowania postaci Apoloniusza jako „boskiego męża”, który jest „,doskonalszy od filozofa” (

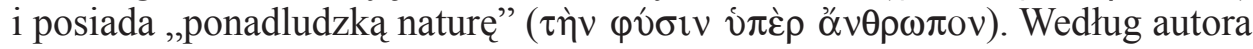
Contra Hieroclem takie błędne założenie prowadzi w następstwie do licznych niekonsekwencji w dziele Filostrata i dyskredytuje zarówno samego autora, jak również opisywaną przez niego postać ${ }^{2}$. Polemista chrześcijański utrzymuje również w swoim traktacie, że Filostrat i jemu podobni autorzy, prezentując w ten sposób osobę Apoloniusza, ośmielają się zuchwale przekraczać

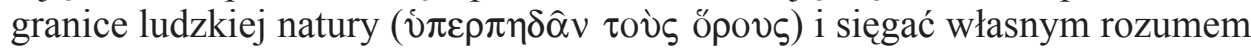

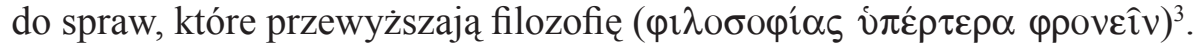

Zamiarem Euzebiusza było zatem ukazanie, jak doktryna chrześcijańska różni się od antycznej wizji „boskich mężów” w kwestii istoty ich egzystencji i misji na ziemi ${ }^{4}$. Dlatego starał się skorygować te błędne, jego zdaniem, przekonania i przekazać własny pogląd dotyczący praw i ograniczeń, jakie występują w naturze. Jego filozoficzno-teologiczny wywód na ten temat, który obejmuje cały szósty rozdział traktatu Przeciwko Hieroklesowi, opiera się w znacznej mierze na istniejącej tradycji filozoficznej i retorycznej5.

Filostratos, Żywot Apolloniusza z Tiany, thum. I. Kania, Kraków 1997, 26-40; M. Szarmach, Pismo Euzebiusza z Cezarei: „Contra Hieroclem”, Acta Universitatis Nicolai Copernici. Historia 27, Nauki Humanistyczno-Społeczne 254, Toruń 1992, 127-134; M. Forrat, Introduction, w: Eusèbe de Césarée, Contre Hiéroclès, introd., trad. et notes par M. Forrat, texte grec établi par É. des Places, SCh 333, Paris 1986, 9-80; S. Borzì, Apollonio di Tiana: da „santo pagano” ad antagonista di Cristo, „Laós” 5 (1998) nr 2, 83-96.

${ }^{2}$ Contra Hieroclem 7, ed. E. des Places, SCh 333, 116; por. 12, 3; 48, 2. Cytowanie traktatu Euzebiusza według łatwiej dostępnego wydania tekstu oryginalnego w serii SCh; dodatkowy podział na akapity według najnowszego wydania w serii The Loeb Classical Library: Eusebius, Reply to Hierocles, w: Philostratus, Apollonius of Tyana, ed. and transl. by Ch.P. Jones, t. 3: Letters of Apollonius. Ancient Testimonia. Eusebius's Reply to Hierocles, The Loeb Classical Library 458, Cambridge Mass. - London 2006, 145-257; tłum. własne.

${ }^{3}$ Contra Hieroclem 5, SCh 333, 108.

${ }^{4}$ Por. S. Campanini, Un cristiano e l'irrazionale: il „, Contra Hieroclem” di Eusebio di Cesarea, „Giornale Ferrarese di Retorica e Filologia” 1 (1991) nr 1, 21. Na temat „boskich mężów” w starożytności zob. G. Fowden, The pagan Holy Man in late antique society, „The Journal of Hellenic Studies” 102 (1982) 33-59; M. Dzielska, , Boscy mężowie”, „Znak” 50 (1998) nr 515, 41-54; G. Anderson, Sage, Saint and Sophist. Holy Men and their associates in the early Roman Empire, London 1994; E. Koskenniemi, Apollonios von Tyana in der neutestamentlichen Exegese. Forschungsbericht und Weiterführung der Diskussion, Tübingen 1994, 64-168; P.J. Achtemeier, Gospel Miracle

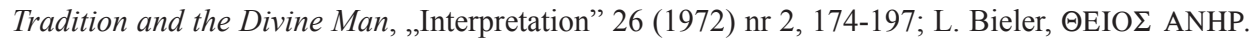
Das Bild des ,,göttlichen Menschen " in Spätantike und Frühchristentum, Bd. 1-2, Wien 1935-1936; O. Weinreich, Antikes Gottmenschentum, „Neue Jahrbücher für Wissenschaft und Jugendbildung” 2 (1926) 633-651.

${ }^{5}$ Szczegółową analizę tego rozdziału pod kątem źródeł, które Euzebiusz mógł wykorzystać w swojej argumentacji, prezentuje M. Kertsch, Traditionelle Rhetorik und Philosophie in Eusebius' Antirrhetorikos gegen Hierokles, VigCh 34 (1980) 145-171. 
Euzebiusz wyraża tutaj przekonanie ${ }^{6}$, że istnieją „nieprzemijające prawa

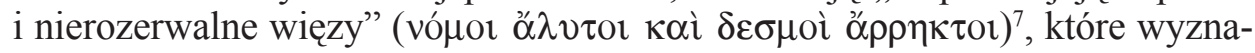
czają naturze pewne granice (őpor $\varphi v ́ \sigma \varepsilon \omega \varsigma)$. Te ograniczenia natury stanowią

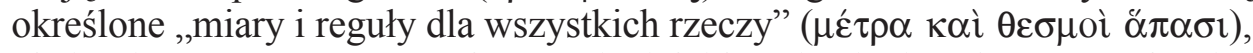
obejmując zarówno ,początek, trwanie, jak i kres istnienia całego wszechświa-

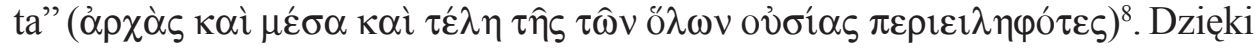
nim cały wszechświat posiada taki właśnie, a nie inny ,mechanizm oraz struk-

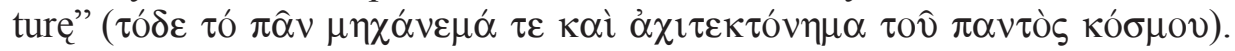

Niepodważalne prawa, wydzielające granice naturze wszystkich bytów i kierujące całym wszechświatem, są wyrazem i stoją na straży „przemądrej

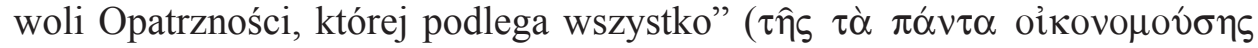

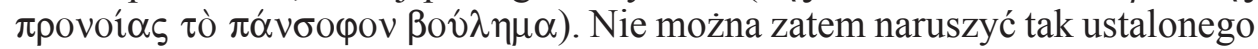

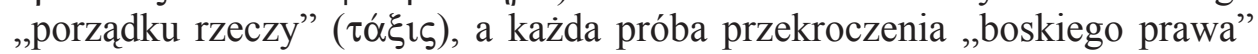
(vó $\mu$ os $\theta \varepsilon \hat{\imath} о \varsigma)$ jest z góry skazana na niepowodzenie, bo na przeszkodzie temu stoi zawsze jakaś „,reguła natury” $(\theta \varepsilon \sigma \mu \text { ò } \varphi v ́ \sigma \varepsilon \omega \varsigma)^{9}$.

Dla poparcia i odpowiedniego zobrazowania swoich twierdzeń Euzebiusz podaje przykłady żyjących istot, które zgodnie z prawami natury mają przyporządkowane określone środowisko do życia. Takie porównania, które stanowiły odniesienie do istot żywych, ograniczonych swoim biotopem, były częstym elementem filozoficznej diatryby ${ }^{10}$. Dla autora Contra Hieroclem jest czymś

${ }^{6}$ Contra Hieroclem 6, 1, SCh 333, 110.

${ }^{7}$ Geneza tego zwrotu sięga Homera (Ilias XV 19-20; Odyssea VIII 274-275), a po nim wykorzystują go późniejsi autorzy starożytni. Kilkakrotnie występuje w dziełach Filona Aleksandryjskiego (np. De confusione linguarum 166; De migratione Abrahami 181; De praemiis et poenis 81). Inne odniesienia zob. Kertsch, Traditionelle Rhetorik, s. 150-151.

${ }^{8}$ To wyrażenie pochodzi od Platona (Leges IV 715E-716A) i jest ono do jednym z najczęściej cytowanych platońskich stwierdzeń zarówno w literaturze pogańskiej, jak i chrześcijańskiej. Euzebiusz cytuje tę formułę jeszcze dwa razy w Praeparatio evangelica (XI 13, 5; XV 5, 2); por. Kertsch, Traditionelle Rhetorik, 151-152; Forrat, SCh 333, 111, przyp. 4; G.F. Chesnut, The first Christian Histories. Eusebius, Socrates, Sozomen, Theodoret, and Evagrius, ThH 46, Paris 1978, 71.

${ }^{9}$ Contra Hieroclem 6, 2, SCh 333, 110.

${ }^{10}$ Diatryba, której początków upatruje się w epoce hellenistycznej, to wykład filozoficzny o charakterze popularnym, najczęściej na tematy etyczne. Twórcami tego rodzaju uprawiania filozofii byli cynicy, którzy starali się, aby ich nauczanie było bardziej przystępne dla prostych ludzi. Taki wykład musiał więc angażować odbiorców i przyciągać ich zainteresowanie, dlatego też filozof prowadził go językiem prostym i w żywej formie, nie pozbawionej teatralności oraz dopuszczającej reakcję słuchaczy w postaci pytań lub replik. Do rozważań filozoficznych wplatano przysłowia, anegdoty, cytaty i przykłady z życia codziennego. Z czasem diatryba stała się popularnym gatunkiem literackim, gdzie autor dla potrzeb swojego wywodu wprowadzał fikcyjnego oponenta i wymyślone kontrargumenty; por. LGS, t. 2, 791-792; W. Capelle - H.I. Marrou, Diatribe, RACh III 990-1009. Najbardziej charakterystyczne przykłady dzieł, które stosowały odniesienia do istot żyjących w swoich naturalnych środowiskach, podaje Kertsch, Traditionelle Rhetorik, s. 152-153 i 166, przyp. 29 i 30 - za szczególnie podobne do rozważań Euzebiusza uznaje on dwa miejsca w dziełach Filona (Quod deterius potiori insidiari soleat 151 i Quis rerum divinarum heres 237). Euzebiusz podejmie ten temat w Teofanii (II 3). Tendencja uproszczenia i spopularyzowania filozofii była typowa 
oczywistym, że ryba, która normalnie żyje w środowisku wodnym, nie może wbrew naturze prowadzić życia na lądzie, a z kolei istota żyjąca na ziemi nie znajdzie $\mathrm{w}$ wodzie trwałej siedziby. Podobnie istota prowadząca życie na ziemi, nawet gdyby chciała, to nie potrafi wzbić się i zawisnąć w powietrzu, tak jak ptaki. Te jednak - w tym przypadku Euzebiusz pisze o orłach - moga przebywać na ziemi, kiedy tylko zechcą i przestaną używać skrzydeł.

Przykład ptaków, które natura obdarzyła możliwością latania w powietrzu, stanowi dla Euzebiusza przesłankę do sformułowania bardziej ogólnego wniosku:

„Ponieważ i to ustalone jest boskimi prawami, że istota żyjąca wysoko w górze jest w stanie zstąpić z wysokości na ziemię, ale nie odwrotnie - to, co żyje nisko na ziemi, nie może unosić się w górę"11.

Tym stwierdzeniem Euzebiusz podsumowuje pierwszą część swoich rozważań na temat ograniczeń, które wynikają z praw rządzących naturą, i wprowadza nas w ten sposób do zasadniczej treści jego wywodu, traktującego o właściwościach natur ludzkiej i boskiej.

Boskie prawa, które porządkują cały wszechświat, obejmują tak samo na-

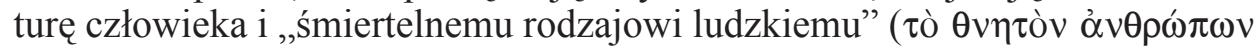
$\gamma \varepsilon \dot{\varepsilon} v o \varsigma)$ wyznaczają także pewne granice. Euzebiusz przyjmuje dualistyczną koncepcję człowieka i uważa, że oba elementy konstytuujące ludzką naturę, zarówno cielesny, jak i duchowy, podlegają ograniczeniom: człowiek nie może przecież unosić swego ciała w powietrzu, a każda bezmyślna próba latania zakończyłyby się dla niego przykrymi skutkami; nie jest też w stanie umysłem dosięgnąć spraw, które przekraczają możliwości jego rozumu, ponieważ takie usiłowania grożą z kolei chorobą ,melancholii” $(\mu \varepsilon \lambda \alpha \gamma \chi 0 \lambda i \alpha \varsigma$ vó $\rceil \mu \alpha)^{12}$.

Bazując na takiej koncepcji ludzkiej natury, Euzebiusz udziela następnie pewnej rady, w której jako najroztropniejsze rozwiązanie proponuje zaakceptowanie przez człowieka swoich naturalnych ograniczeń:

„Wtedy jedynie okazałby zdrowy rozsądek, gdyby nosił swoje ciało, chodząc

dla tzw. „drugiej sofistyki” - na ten temat zob. C. Moreschini, Aspetti della cultura filosofica negli ambienti della Seconda Sofistica, ANRW II 36. 7, 5103-5104.

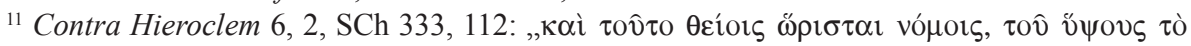

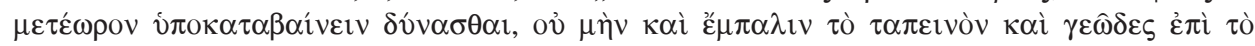

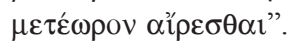

${ }^{12}$ Tamże 6, 3, SCh 333, 112. Na temat tej choroby i jej rozumienia jako „pomieszanie zmysłów” istnieje pokaźna literatura; najogólniej można stwierdzić, że termin ten posiada znaczenie zarówno medyczne, jak i moralne. Być może użycie tego terminu przez Euzebiusza jest jakąś aluzją do Porfiriusza, który pisze o własnej „melancholii” w Żywocie Plotyna (11, 11), zob. Campanini, Un cristiano, s. 22-23; A. Traverso, w: Eusebio di Cesarea, Contro Ierocle, introd., trad. e note a cura di A. Traverso, Collana di testi patristici 137, Roma 1997, 44, przyp. 19. 
po ziemi przystosowaną do tego parą nóg, a z drugiej strony, gdyby opierał swoją duszę na wykształceniu filozoficznym"13.

Zdrowy rozsądek domaga się więc prowadzenia życia zgodnego z własną naturą $^{14}$, czyli twardego stąpania po ziemi oraz dbałości o rozwój duchowy i umysłowy przez uprawianie filozofii. Z powyższego stwierdzenia można ponadto wywnioskować, że dla Euzebiusza akceptacja ograniczeń ludzkiej natury nie wyklucza wcale potrzeby jej doskonalenia. Świadczy o tym fakt, iż, jakby starając się być zrozumiałym dla pogańskiego czytelnika, podkreśla on wartość tradycyjnego wychowania, którego szczytem była formacja filozoficzna. Jej celem w starożytności, co widoczne jest również w tekście Euzebiusza, było kształtowanie w człowieku pierwiastka duchowego ${ }^{15}$.

Jednakże filozofia nie jest w stanie dać człowiekowi odpowiedzi na wszystkie nurtujące go pytania i wątpliwości, gdy dotyczą one zwłaszcza spraw, które wykraczają poza granice ludzkiej natury. Dlatego autor Contra Hieroclem doradza następnie:

„Może również modlić się, żeby przybył mu z pomocą ktoś z wysokości, z niebiańskiej krainy, i objawił się mu jako nauczyciel zbawienia, które stamtąd właśnie pochodzi"16.

Z zalecenia tego wynika, że według Euzebiusza człowiek na podstawie swoich zdolności poznawczych nie potrafi ogarnąć rzeczywistości nadprzyrodzonej. Nie jest też zdolny sam z siebie osiagnąć zbawienia ( $\sigma \omega \tau \eta \rho i ́ \alpha)$, które do tej właśnie sfery należy. Dlatego właśnie jego ograniczona natura potrzebuje objawienia istoty pochodzącej ,z wysokości, z niebiańskiej krainy” (ő

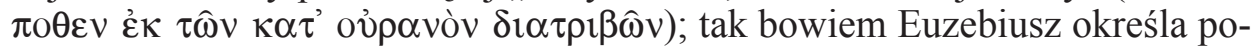
nadziemską rzeczywistość Boską. Człowiekowi ze swej strony pozostaje jedynie prosić w modlitwie ( $\varepsilon \hat{\xi} \xi \alpha \iota \tau o$ ) o taką zbawczą ingerencję z góry. Istnieje zatem dla niego jakaś optymistyczna perspektywa, którą autor Contra Hieroclem ukazuje nie z punktu widzenia gnozeologicznego, ale soteriologicznego ${ }^{17}$.

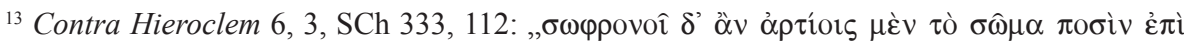

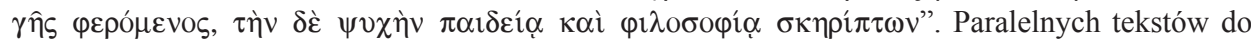
tego wskazania Euzebiusza M. Kertsch (Traditionelle Rhetorik, s. 153-154) dopatruje się u PseudoArystotelesa (De mundo I 391A, 8n.), w Corpus Hermeticum (X 25) oraz w pismach Filona (De opificio mundi 147; De mutatione nominum 179) i Maksyma z Tyru (Dissertationes X 9C; XI 10D-E).

${ }^{14}$ Jest to idea typowo stoicka; por. S. Lilla, Clement of Alexandria. A study in Christian Platonism and Gnosticism, Oxford 1971, 92-93; Chesnut, The first Christian Histories, s. 72-75.

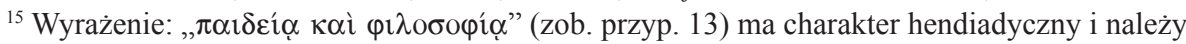
je tłumaczyć jako: „wykształcenie filozoficzne”, ponieważ Euzebiusz nawiązuje tutaj do programu wykształcenia antycznego, którego ostatnim etapem i zarazem zwieńczeniem była formacja filozoficzna, por. Forrat, SCh 333, 112, przyp. 2; Kertsch, Traditionelle Rhetorik, s. 154.

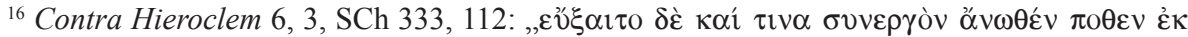

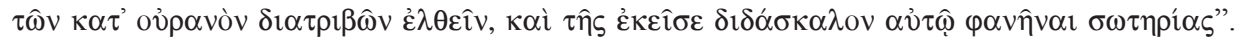

${ }^{17}$ Por. Kertsch, Traditionelle Rhetorik, s. 153. 
Wyrażając pogląd o możliwości ingerowania z góry w ludzką egzystencję, Euzebiusz wprowadza swoją koncepcję „boskiego męża”. Z zacytowanego

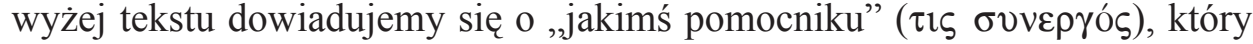
zstępuje z nieba na ziemię i objawia się tu jako „nauczyciel” ( $\delta$ ı́́́ $\sigma \kappa \alpha \lambda \circ \varsigma)$ ludzi w sprawach wykraczających poza ludzką naturę.

Następnie Euzebiusz stara się jeszcze bardziej przybliżyć rolę, jaką owa istota ze sfery boskiej pełni $\mathrm{w}$ relacjach $\mathrm{z}$ ludźmi. Posługuje się w tym celu dwoma obrazowymi porównaniami: do lekarza, który przychodzi z wizytą do chorego, i do nauczyciela, który zniża się do poziomu wiedzy swojego ucznia. Te przykłady, zaczerpnięte $\mathrm{z}$ codziennego życia i chętnie stosowane w tradycji patrystycznej ${ }^{18}$, stanowią dla Euzebiusza potwierdzenie zasadniczej tezy jego wywodu, że tylko taka sytuacja jest możliwa, kiedy:

„ten, kto przebywa gdzieś w górze i żyje na wysokości, zniża się do tych na niskości, ale nie odwrotnie"19.

Kontynuując swój filozoficzny wywód o prawach i ograniczeniach natury, Euzebiusz wyraża przekonanie, że taki porządek zstępujący w relacjach boskiej natury z naturą ludzką jest zgodny z „regułą Bożej Opatrzności” (őpos

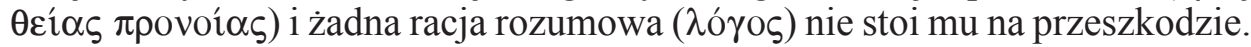
Możliwość zaistnienia relacji Bosko-ludzkich jest wyrazem dobroci i troski Boga; wskazują na to epitety, którymi Euzebiusz określa naturę boską ( $\theta \varepsilon i ́ \alpha$

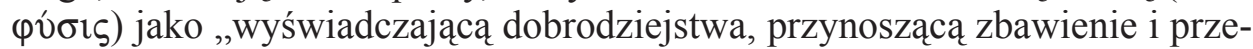

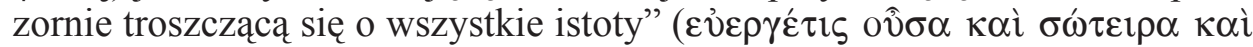

${ }^{18} \mathrm{~Np}$. przez Orygenesa (Contra Celsum IV 12) i Jana Chryzostoma (In I Epistolam ad Corinthios hom. 22, 3); por. Kertsch, Traditionelle Rhetorik, s. 156.

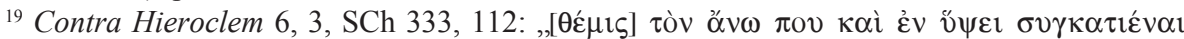

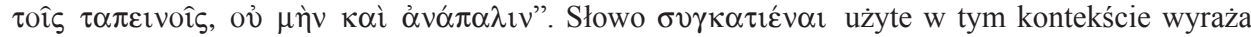
ideę zstępowania istoty niebiańskiej i jej zniżania się do poziomu ludzkiego. Według autora Contra Hieroclem jest to niezbędny warunek, aby doszło do kontaktu człowieka ze sferą nadprzyrodzona. Komentarz do tego stwierdzenia znajduje się także w innych dziełach Euzebiusza, gdzie można natknąć się na takie oto zastrzeżenie, że „w innym wypadku byłoby jaką́s bezbożnością i nie godziłoby się, żeby ten, kto znajduje się poza i ponad wszystkim łączył się z podlegającą zniszczeniu

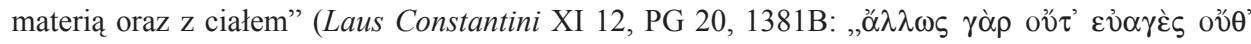

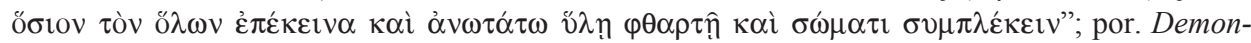
stratio evangelica IV 6, 3). Idea konieczności ,zstąpienia” Boga, aby doszło do kontaktu z ludźmi, jest jednym z przypadków, kiedy stanowiska chrześcijańskie i pogańskie są wyraźnie zbieżne - taki pogląd jest wyrażony m.in. w dziełach Filona (De Abrahamo 76), Plutarcha (Numa 4, 6; Romulus 28, 7), Maksyma z Tyru (Dissertationes XXXVI 2A n.), Juliana Apostaty (Oratio V 171B) i Himeriusza (Epithalamia in Severum 10). Ten synkretyzm myśli chrześcijańskiej i pogańskiej ma bez wątpienia swoje źródło w słynnym stwierdzeniu Platona: „Bóg nie ma relacji z człowiekiem, ale przez niego [Erosa] odbywa się wszelkie obcowanie i wszelka rozmowa bogów z ludźmi" (Plato,

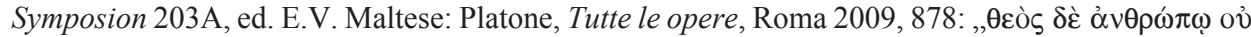

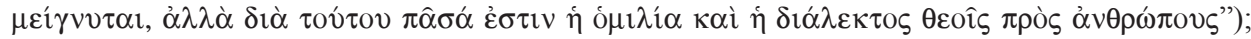
por. A. Traverso, w: Eusebio di Cesarea, Contro Ierocle, s. 45, przyp. 22; Forrat, SCh 333, 112-113, przyp. 3; Kertsch, Traditionelle Rhetorik, 156-157. 


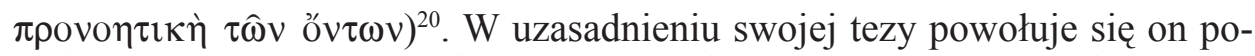
nadto wprost na autorytet Platona, cytując dosłownie jego słynne zdanie:

„Ponieważ, według Platona, Bóg był dobry, a u tego, kto jest dobry, nie powstaje żadna zawiść w jakiejkolwiek sprawie"21.

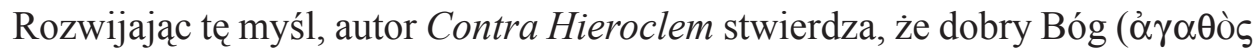

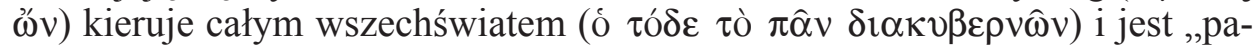

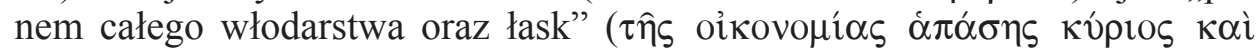

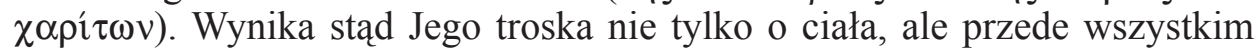
o dusze, którym został powierzony „dar nieśmiertelności i wolnej woli” ( $\tau$ ò

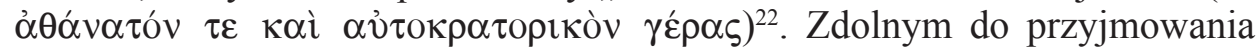
( $\alpha \nu \tau \imath \lambda \eta \pi \tau \imath \kappa \alpha i ́)$ boskich darów duszom Pan i Władca całego wszechświata udziela obficie ( $\alpha \varphi \theta o ́ v \omega \varsigma)$ swoich łask, porównywanych przez autora traktatu

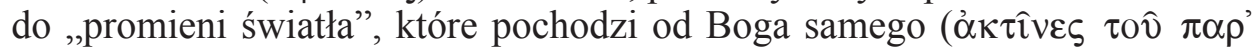
$\left.\dot{\varepsilon} \alpha \nu \tau 0 \hat{v} \varphi \omega \tau \tau_{\varsigma}\right)^{23}$.

${ }^{20}$ Contra Hieroclem 6, 4, SCh 333, 114.

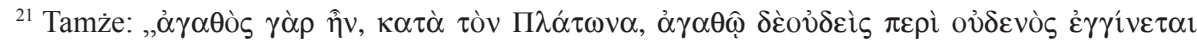
$\varphi \theta$ óvos” (Plato, Timaeus 29E). Wśród uczonych powszechna jest opinia, że to zdanie Platona stanowi niejako „ewangelię platonizmu”. Chrześcijanie znajdywali w nim potwierdzenie dla swojego przekonania, że to właśnie dobroć Boga skłoniła go do stworzenia świata. Na takie założenie można również często natrafić u Filona (np. De opificio mundi 21; De specialibus legibus II 173, 249; De praemiis et poenis 39), por. Kertsch, Traditionelle Rhetorik, s. 157 i 168, przyp. 66-67. Na temat platonizmu Euzebiusza zob. A. Dempf, Der Platonismus des Eusebius, Victorinus und Pseudo-Dionysius, München 1962; É. des Places, Eusèbe de Césarée commentateur. Platonisme et Écriture Sainte, ThH 63, Paris 1982.

${ }^{22}$ Contra Hieroclem 6, 4, SCh 333, 114. Przymiotnik $\alpha$ kontekście jako termin techniczny - w filozofii greckiej dla wyrażenia wolnej woli człowieka stoso-

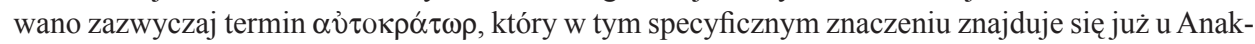
sagorasa; por. Kertsch, Traditionelle Rhetorik, s. 158 i 169, przyp. 77 i 78. Sam Euzebiusz używa

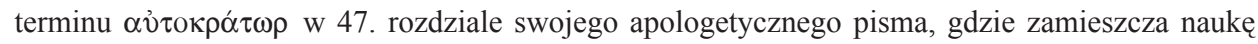
o Bożej Opatrzności i wolnej woli człowieka (SCh 333, 208).

${ }^{23}$ Contra Hieroclem 6, 4, SCh 333, 114. W tekście Euzebiusza to obrazowe porównanie dobroci Boga do promieniującego światła wiąże się z ukazaniem zaraz potem misji istoty boskiej, posłanej ze sfery niebiańskiej i będącej przejawem tego Bożego promieniowania. Ten motyw stanowi również przykład synkretyzmu doktryny chrześcijańskiej z filozofią pogańską. Za podstawę odniesień może w tym przypadku służyć słynny fragment z dzieła Platona (Respublica VI 508B n.) oraz teksty biblijne (np. Mdr 7, 26; Hbr 1, 3; 1J 1, 5). Przed Euzebiuszem takie porównanie było stosowane przez

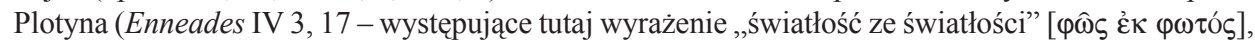
znajduje się również w nicejskim wyznaniu wiary; V 1, 6; 3, 12; VI 9, 9), Klemensa Aleksandryjskiego (Stromata VII 5, 5; Protrepticus X 98, 4) i Orygenesa (De principiis I 2, 4; 2, 7; IV 4, 1; Commentarii in Evangelium Joannis II 23; XIII 25; In Jeremiam hom. IX). U Euzebiusza podobne motywy spotykamy jeszcze w Laus Constantini (I 2, 6; VI 18). Obraz Boga jako światła, które promieniuje, kontynuują następnie pozostający w dużej zależności od doktryny neoplatońskiej Ojcowie Kapadoccy i Pseudo-Dionizy Areopagita - szczegółowe odniesienia zob. Kertsch, Traditionelle Rhetorik, s. 159-160; S. Lilla, Dionigi l'Areopagita e il platonismo cristiano, Brescia 2005, 46, 55, 100, 119, 132, 153-155; C. Moreschini, Storia della filosofia patristica, Brescia 2004, 546-549. 
2. Wysłannik niebios. W koncepcji Euzebiusza przejawem takiego promieniowania Bożej dobroci, wypływającym z troski o ludzkie dusze i mającym na celu ich pożytek, jest właśnie zstąpienie na ziemię istoty, która pochodzi ze sfery niebiańskiej. Autor traktatu Przeciwko Hieroklesowi stwierdza bowiem dalej, że niekiedy Bóg posyła $(\dot{\varepsilon} \kappa \pi \varepsilon \dot{\varepsilon} \mu \pi \omega v)$,ze swojego otoczenia

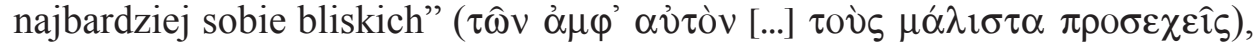
aby w ten sposób mieszkańcom ziemi ofiarować „zbawienie i pomoc” (عis

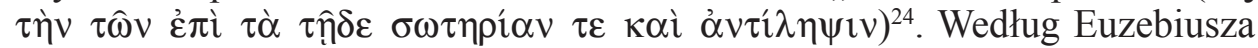
w sferze nadziemskiej istnieje więc pewna hierarchia bytów niebiańskich, które znajdują się wokół Boga. Tylko jemu najbliżsi są posyłani, aby realizować jego zbawczą misję. Zastosowanie tutaj liczby mnogiej wskazywałoby na za-

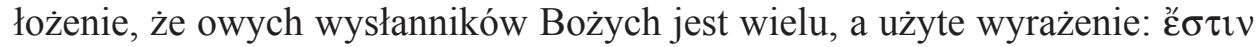
ő $\tau \varepsilon$ sugeruje, że posyłanie istoty ze sfery boskiej na ziemię nie stanowi jakiejś jednorazowej akcji, ale jest powtarzane od czasu do czasu.

Kolejna część filozoficznego wywodu Euzebiusza dotyczy skutków posłannictwa owej niebiańskiej istoty:

„Gdyby któremuś z nich się powiodło, to wówczas, po oczyszczeniu swojego umysłu i rozproszeniu mgły śmiertelności, ten naprawdę będzie uznany za boskiego, ponieważ będzie nosił w duszy obraz jakiegoś wielkiego boga"25.

Znacząca pozycja istoty wysłanej ze sfery niebiańskiej zależy zatem od pomyślnego wypełnienia jej misji, jak również od pewnego samodoskonalenia się. Wyrażenie ,po oczyszczeniu swojego umysłu i rozproszeniu mgły śmier-

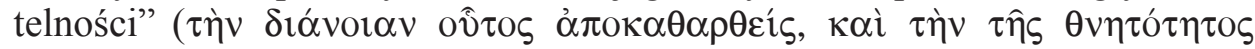

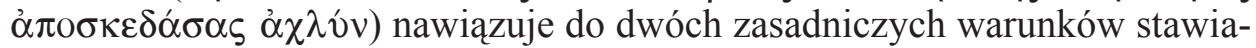
nych zwykle w filozofii „boskim mężom”. Podstawy sformułowania tych warunków należy szukać w platońskiej teorii o świecie idei ${ }^{26}$. Powyższy fragment, który charakteryzuje w głównych rysach ideał „,boskiego męża”, osiaga swój szczytowy punkt w stwierdzeniu: „naprawdę będzie uznany za boskie-

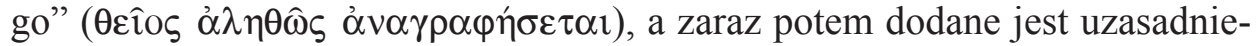
nie: ,ponieważ będzie nosił w duszy obraz jakiegoś wielkiego boga” ( $\mu \varepsilon \dot{\gamma} \alpha \mathrm{v}$

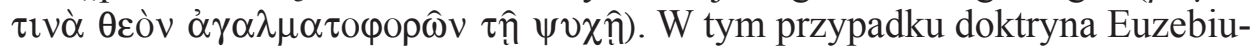
sza stanowi wyraźne odzwierciedlenie poglądów Filona Aleksandryjskiego, według którego Bóg powinien mieszkać w doskonałej, oczyszczonej duszy i dlatego taki przywilej może być udzielony jedynie komuś, kto jest całkowicie bezgrzeszny ${ }^{27}$.

${ }^{24}$ Contra Hieroclem 6, 4, SCh 333, 114.

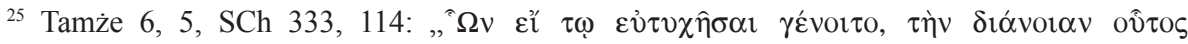

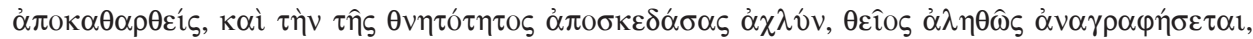

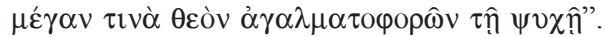

${ }^{26}$ Por. Kertsch, Traditionelle Rhetorik, s. 160-161.

${ }^{27}$ Według Filona dusza jest miejscem zamieszkania Boga, jego „domem” albo „świątynią”, a jej przeznaczeniem jest nosić w sobie wizerunek spośród wszystkich najbardziej podobny do 
Wypełniając swoją misję na ziemi, wysłaniec niebios powinien jakoś oddziaływać na tych, do których zostaje posłany. Euzebiusz stwierdza więc, że tak

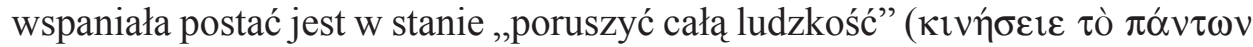

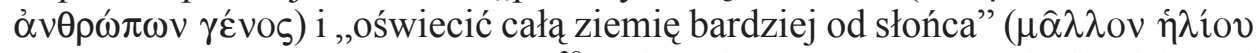

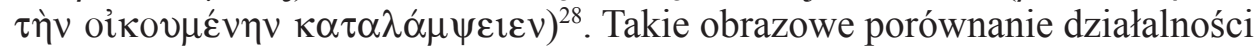
istoty niebiańskiej do światła, które oświeca zamieszkałą ziemię i przewyższa swoim blaskiem nawet światło słoneczne, stanowi prawdopodobnie aluzję do istniejącego już w literaturze toposu ${ }^{29}$. Trudno też oprzeć się wrażeniu, że Euzebiusz nawiązuje tutaj do licznych tekstów biblijnych, gdzie mowa jest o światłości oświecającej świat, która utożsamiana jest z Chrystusem (por. np. Iz 9, 1; 60, 1-2. 19-20; Łk 1, 78-79; J 1, 4-5. 9; 3, 19; 8, 12; 9, 5; 12, 35-36. 46; Rz 13, 12-14; 2Kor 4, 6; 1P 2, 9; 1J 2, 8-11; Ap 21, 23-24). Autor Contra Hieroclem wydaje się kontynuować w ten sposób ustaloną już wcześniej tendencję apologetyczną, dążącą do ukazania wyższości wiary chrześcijańskiej nad rozpowszechnionym wówczas kultem boga Słońca i różnymi kultami misteryjnymi, które były związane z cyklem solarnym ${ }^{30}$. Wynikiem objawienia się

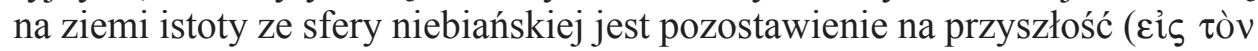

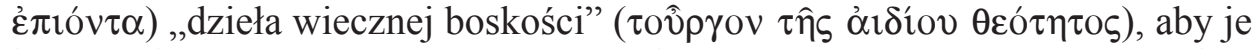
kontemplowano ( $\sigma v v o \rho \hat{\alpha} \sigma \theta \alpha \imath$ ). Nie trudno zauważyć, że w swoim wywodzie Euzebiusz wyraźnie akcentuje najpierw powszechny, a następnie ponadczasowy charakter działalności wysłannika niebios. Wskazuje w ten sposób na podstawowe kryteria autentyczności jego misji i odwołuje się do wcześniejszej części traktatu, gdzie wykazywał, że właśnie taki charakter ma zbawcze

\footnotetext{
Boga. W tym kontekście używa (De opificio mundi 137) on wyrażenia: „ $\propto \gamma \alpha \lambda \alpha \mu \alpha \tau o \varphi о \rho \eta ́ \sigma \varepsilon \imath v$

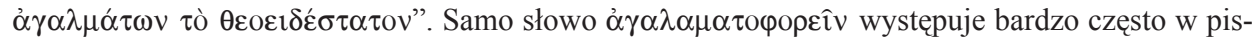
mach żydowskiego filozofa z Aleksandrii, por. Kertsch, Traditionelle Rhetorik, s. 161 i 170, przyp. 96; M. Delcogliano, Eusebian theologies of the Son as the Image of God before 341, JECS 14 (2006) nr 4, 459-484.

${ }^{28}$ Por. Contra Hieroclem 6, 4, SCh 333, 114.

${ }^{29}$ Taki motyw można znaleźć np. w pismach Filona (De praemiis et poenis 37), Juliana Apostaty (Oratio IV 145B), Himeriusza (Oratio VIII 7) i samego Euzebiusza (Laus Constantini I 6; VI 18); por. Kertsch, Traditionelle Rhetorik, s. 162; por. też wyżej przyp. 23.

${ }^{30}$ Taki motyw spotykamy np. u Klemensa Aleksandryjskiego (Protrepticus XII 119, 3); o tym, że Bóg musi być koniecznie jaśniejszy od materialnego słońca, którego jest Stwórcą, pisał już Filon (De specialibus legibus I 279), por. Kertsch, Traditionelle Rhetorik, s. 162. Kulty związane z cyklem solarnym opierały się na przekonaniu o porządku panującym we wszechświecie, który oddziałuje na życie człowieka. Przygotowanie do przyjęcia systemów solarnych Wschodu dała religia grecka, a zwłaszcza filozofia (pitagoreizm, stoicyzm). Do tych systemów należały kulty pochodzenia bądź syryjskiego (Baal, Juppiter Dolichenus), bądź irańskiego (Mitra). Cesarze dynastii Sewerów w nich właśnie dostrzegli poważną szansę stworzenia nowej religii imperialnej. Na temat popularności kultu boga Słońca i kultów misteryjnych w okresie późnego cesarstwa zob. D. Esser, Formgeschichtliche Studien zur hellenistischen und zur frühchristlichen Literatur unter besonderer Berücksichtigung der Vita Apollonii des Philostrat und der Evangelien, Bonn 1969, 44-47; M. Jaczynowska, Dzieje Imperium Romanum, Warszawa 1995², 324-325.
} 
dzieło Chrystusa, czego wcale nie można powiedzieć o skutkach działalności Apoloniusza z Tiany ${ }^{31}$.

Do tego wątku Euzebiusz powraca jeszcze w swoim polemicznym dziele, już w ścisłym związku z krytyką postaci Tianejczyka. Wyraża on przekona-

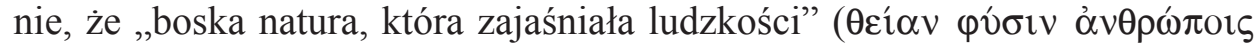

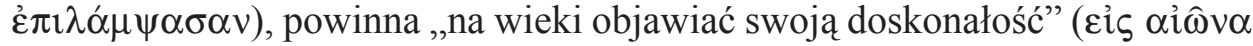

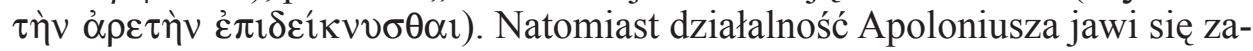

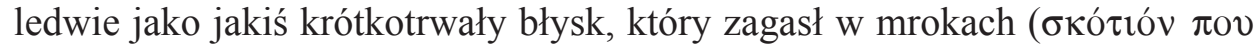

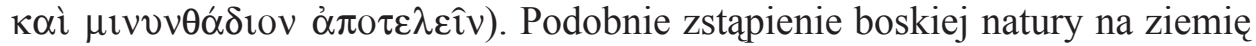
powinno być ,źródłem dobrodziejstw dla niezliczonych rzesz ludzi, i to nie tylko dla tych, którym dała się poznać, ale także dla przyszłych pokoleń ludz-

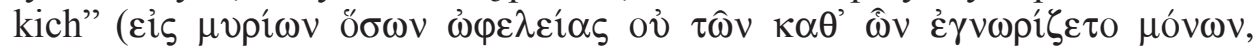

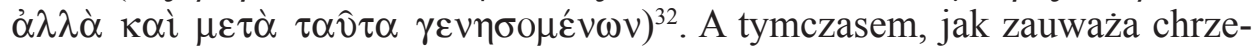
ścijański autor, skutki działalności Apoloniusza dotknęły jedynie jego ucznia Damisa i niewielu innych współczesnych mu ludzi.

Oprócz „dzieła wiecznej boskości”, którego skutki obejmują wielu ludzi i sięgają $\mathrm{w}$ przyszłość, istota zstępująca $\mathrm{z}$ niebios na ziemię powinna także przekazać ludzkości ,przykład wypełnionej bóstwem natury, który nie ustę-

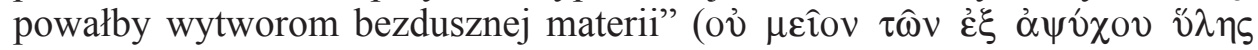

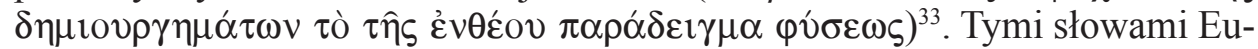
zebiusz wyraźnie oddziela ludzkie wytwory materialne, które są „,bezduszne" (ڤ̋ $\psi v \chi \alpha)$, od wartości, które mają charakter duchowy i są pochodzenia boskiego. Porusza tutaj ponadto istotny problem apologetyczny, obecny także w innych jego dziełach, który dotyczy bałwochwalczego kultu posagów i innych przedstawień bóstw pogańskich ${ }^{34}$. Takiemu kultowi materialnych (czyli „,bezdusznych”) wizerunków pogańskich bogów autor Contra Hieroclem przeciwstawia więc swój pogląd o istocie zstępującej z nieba, która jedynie może ludziom objawić wielkość Boga, ponieważ posiada naturę wypełnioną boskością i nosi w swej duszy jego obraz.

Filozoficzno-teologiczne rozważania na temat praw natury i jej ograniczeń oraz zstąpienia boskiej istoty na ziemię prowadzą Euzebiusza do wniosku, że tylko w ten sposób ludzka natura ma możliwość zetknięcia się z ponadludzką

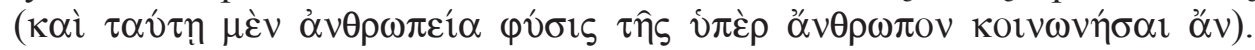
W żadnym innym razie nie należy, jego zdaniem, przekraczać granic wyzna-

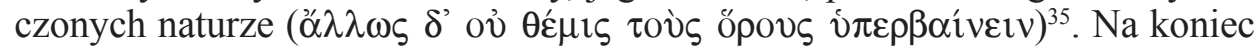
Euzebiusz raz jeszcze powraca do analogii ze światem przyrody i podsumowuje swój wywód stwierdzeniem, że podobnie jak istota, która nie posiada

\footnotetext{
${ }^{31}$ Por. Contra Hieroclem 4, 1-2.

${ }^{32}$ Contra Hieroclem 7, SCh 333, 116.

${ }^{33}$ Contra Hieroclem 6, 5, SCh 333, 114.

${ }^{34}$ Por. Laus Constantini IX 8; XIV 2-3; zob. Kertsch, Traditionelle Rhetorik, s. 162-163 i 171, przyp. 106-109.

${ }^{35}$ Contra Hieroclem 6, 5, SCh 333, 114.
} 
skrzydeł, nie powinna dążyć do naśladowania ptaków w ich zdolności latania, tak też człowiek nie powinien ,wtrącać się do spraw związanych ze sferą de-

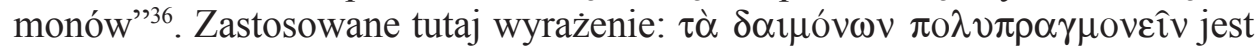
rozumiane i odczuwane przez Euzebiusza w sposób typowo helleński ${ }^{37}$, przy czym terminu $\delta \alpha i ́ \mu o v \varepsilon \varsigma$ używa on na określenie złych mocy nadnaturalnych, które utożsamia z bogami i herosami religii pogańskiej ${ }^{38}$. Autor Contra Hieroclem potępia w ten sposób wszelkie starania mające na celu przekraczanie granic ludzkiej natury i wścibskie zajmowanie się sprawami, które należą do świata demonów. Dążenia takie są dla niego równoznaczne z uprawianiem magii ${ }^{39}$.

\section{$* * *$}

Filozoficzno-teologiczny wywód, zawarty w szóstym rozdziale traktatu Przeciwko Hieroklesowi, z punktu widzenia chrześcijańskiej doktryny jest dosyć zawiły, a jego konkluzje wydają się być wątpliwej ortodoksyjności ${ }^{40}$. Szczególnie tajemniczo w koncepcji Euzebiusza prezentuje się owa postać wysłannika niebios, która została przeciwstawiona wizerunkowi Apoloniusza z Tiany, nakreślonemu przez Filostrata. Kontekst całego traktatu wskazuje, że niewatpliwie chodzi tutaj o Chrystusa, ale akurat w tym miejscu autor Contra Hieroclem jakby świadomie pomija imię Jezusa oraz typowe tytuły chrystologiczne: Chrystus, Pan, Zbawiciel, których używa w innych miejscach swojego polemicznego pisma ${ }^{41}$. W rozważaniach Euzebiusza niezbyt klarownie ukazana została także idea synostwa Bożego i inkarnacji Chrystusa oraz idea jego jedynej i niepowtarzalnej misji. Jest mowa jedynie o „posyłaniu” przez Boga kogoś z jego najbliższego otoczenia i o „zstąpieniu” na ziemię niebiańskiej istoty. Nie ma również żadnego wyraźnego nawiązania do tekstów biblijnych ${ }^{42}$, wiele jest natomiast odniesień i aluzji do istniejącej już tradycji filozoficznej.

Można wobec tego przypuszczać, że Euzebiusz unika tutaj wyraźnego prezentowania elementów wiary chrześcijańskiej, które były szczególnie trudne

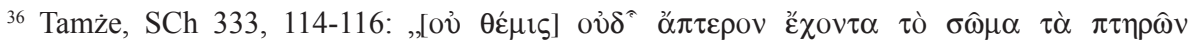

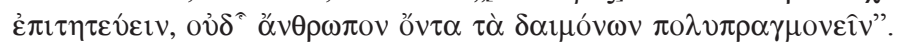

${ }^{37}$ To wyrażenie sięga swą genezą słynnej platońskiej definicji sprawiedliwości (Respublica IV

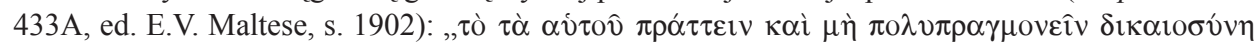

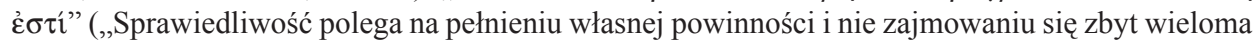
sprawami"); znajduje ono swą paralelę w stwierdzeniu Epikteta (Dissertationes III 22, 97) i jest typowe dla kultury greckiej; por. Kertsch, Traditionelle Rhetorik, s. 163 i 171, przyp. 110; Lilla, Clement of Alexandra, s. 80.

${ }^{38}$ Por. Contra Hieroclem 10, 1; 28-30; 35; Forrat, SCh 333, 116-117, przyp. 1. Na temat demonologii Euzebiusza zob. O. Zink, Introduction, w: Eusèbe de Césarée, La préparation évangélique. Livres IV-V, 1-17, SCh 262, Paris 1979, 7-11 (Les démons).

${ }^{39}$ Por. Forrat, Introduction, SCh 333, 62; taż, Notes complémentaires, SCh 333, 219-224.

${ }^{40}$ Por. Campanini, Un cristiano, s. 21-22.

${ }^{41}$ Por. Contra Hieroclem 1 i 4.

${ }^{42}$ Tak jak to ma miejsce w czwartym rozdziale traktatu. 
do przyjęcia dla filozofów pogańskich. Nadaje natomiast tej części swojego traktatu charakter wykładu filozoficznego, który stanowiłby teoretyczny fundament jego polemiki i który przemawiałby jakoś do pogańskiego intelektualisty $^{43}$. Sformułowana przez Euzebiusza doktryna o prawach, które z ustanowienia Bożej Opatrzności istnieją we wszechświecie, o ograniczeniach, jakim podlega ludzka natura, a także o możliwości zstąpienia na ziemię boskiej istoty ma na celu uświadomienie odbiorcy, że te ogólne zasady filozoficzne znajdują konkretne potwierdzenie w osobie Jezusa Chrystusa, czego nie można wcale powiedzieć o postaci Apoloniusza, wykreowanej przez Filostrata i faworyzowanej przez Hieroklesa.

W swym filozoficzno-teologicznym wykładzie Euzebiusz stara się zatem wyjaśnić, dlaczego uważa za zbędne udowadnianie wyższości Chrystusa nad Apoloniuszem. Dla autora Contra Hieroclem wielkość Chrystusa wynika nie tylko z powszechnych i ponadczasowych skutków jego działania, ale przede wszystkim z jego natury i rangi ${ }^{44}$. Wysłannik niebios, według koncepcji Euzebiusza, uczestniczy w boskiej naturze i objawia ją ludziom, przekazuje im Boże dary, przynosi zbawienie i jedynie dzięki niemu człowiek ma możliwość kontaktu ze sferą boską. Pełni zatem rolę pośrednika między Bogiem a ludzkością. Tak ukazana idea pośrednictwa stanowi nawiązanie do poglądów Filona Aleksandryjskiego, Klemensa Aleksandryjskiego i Orygenesa ${ }^{45}$. Jeżeli ponadto weźmie się pod uwagę wskazaną przez autora Contra Hieroclem potrzebę doskonalenia się tej istoty posłanej ze sfery niebiańskiej, można wówczas dopatrywać się w wywodzie Euzebiusza tendencji subordynacjonistycznych oraz zapowiedzi jego przyszłej sympatii dla arianizmu ${ }^{46}$.

${ }^{43}$ Taki właśnie charakter miało nauczanie Orygenesa w założonej przez niego szkole w Cezarei, gdzie Euzebiusz zdobywał wykształcenie pod kierunkiem swego mistrza, Pamfila, który był najznakomitszym uczniem Orygenesa. Szkoła w Cezarei miała raczej charakter misyjny - jej nauki były kierowane do młodych pogan sympatyzujących z chrześcijaństwem, ale niekonieczne zdecydowanych przyjąć chrzest. Orygenes wprowadzał ich w doktrynę chrześcijańską, nauczając filozofii, której główną inspiracją był medioplatonizm, i prezentując im jego chrześcijańską wersję. Jeżeli jego uczniowie chcieli później zostać chrześcijanami, otrzymywali wówczas właściwe nauczanie katechetyczne, por. H. Crouzel, Orygenes, tłum. J. Margański, wyd. 2, Kraków 2004, 52-53, zob. też przyp. 99; A. Kofsky, Eusebius of Caesarea against paganism, Leiden - Boston - Köln 2000, 12-13.

${ }^{44}$ Por. Forrat, Introduction, SCh 333, 62-63.

${ }^{45}$ Filon w podobny sposób prezentował funkcję kapłana (De specialibus legibus I 116; IV 191192), natomiast Orygenes - postać Mojżesza (Contra Celsum I 19). Mamy tu do czynienia z odczytaniem judaistyczno-chrześcijańskim postaci „boskiego męża” o pochodzeniu filozoficznym, por. Kertsch, Traditionelle Rhetorik, s. 154-155; Traverso, w: Eusebio di Cesarea, Contro Ierocle, 44, przyp. 21. O funkcji pośrednictwa Chrystusa u Klemensa zob. Lilla, Clement of Alexandra, s. $158-163$.

${ }^{46} \mathrm{O}$ subordynacjonizmie i arianizmie zob. M. Simonetti, Subordinazionismo, NDPAC III 5155; tenże, Ario - Arianesimo, NDPAC I 503-512. Na temat subordynacjonizmu Euzebiusza oraz podobieństw i różnic jego poglądów z doktryną ariańską zob. Lilla, Dionigi l'Areopagita, s. 58-59; M. Simonetti, La crisi ariana nel IV secolo, SEA 11, Roma 1975, 60-66. 
Nie ulega wątpliwości, że swoim filozoficznym wykładem, który znajduje się w szóstym rozdziale traktatu Przeciwko Hieroklesowi, Euzebiusz dokonuje próby pogodzenia filozofii pogańskiej z doktryną chrześcijańską. Popisuje się znajomością myśli helleńskiej, judaistycznej i chrześcijańskiej, która związana była przede wszystkim ze środowiskiem platońsko-aleksandryjskim. Czyni to do tego stopnia, że każde niemal zdanie może być tutaj traktowane jako cytat albo jako aluzja i bardzo trudne jest wyodrębnienie w tym wywodzie oryginalnej myśli samego Euzebiusza ${ }^{47}$. Widocznie zależało mu na tym, aby jego argumentacja była poparta przez uznane autorytety filozoficzne. Niewątpliwie mamy tu do czynienia z nowatorskim, jak na tamte czasy, sposobem pisania apologii, dostosowanym do nowych warunków, jakie nastały dla chrześcijaństwa po ustaniu prześladowań ${ }^{48}$.

Można oczywiście powątpiewać, czy wywód Euzebiusza o zstapieniu na ziemię boskiej istoty był przekonujący dla Hieroklesa i innych intelektualistów pogańskich ${ }^{49}$. Można również utrzymywać, że sposób zebrania wielu motywów i zasobu pojęciowego z istniejącej już tradycji filozoficznej jest niespójny i powierzchowny ${ }^{50}$. Takie opinie nie podważająjednak przeświadczenia o gruntownym wykształceniu oraz o wielkiej erudycji autora Contra Hieroclem.

\section{THE CONNECTION BETWEEN THE CHRISTOLOGY AND THE THEORY OF THE LAWS OF NATURE IN THE TREATISE OF EUSEBIUS OF CAESAREA AGAINST HIEROCLES}

\section{(Summary)}

The apologetic treatise Against Hierocles is a polemical reply of Eusebius of Caesarea to an antichristian work of Sossianus Hierocles who drew a comparison between Apollonius of Tyana and Christ. The philosophical aspect of the Eusebius' polemics contains his critique of the image of Apollonius as a „divine man” in the Philostratus' The Life of Apollonius of Tyana. Eusebius negates the alleged divinity of the hero of Philostratus on the ground of the providential conception of the world, according to which human nature, in virtue of the order established by the Providence, is not able to rise to divine because of its limits. An approach of both natures is possible solely through a mission of a being that belongs to the heavenly sphere and is illuminated and sent by God. Only the envoy of heavens, who brings the salvation to the whole human race and leaves ,the effects of eternal divinity" to people, can be really considered divine.

\footnotetext{
${ }^{47}$ Por. Szarmach, Pismo Euzebiusza z Cezarei, s. 131.

${ }^{48}$ Por. Moreschini, Storia della filosofia patristica, s. 327.

${ }^{49}$ Por. Forrat, Introduction, SCh 333, 62; Szarmach, Pismo Euzebiusza z Cezarei, s. 131.

${ }^{50}$ Por. Moreschini, Storia della filosofia patristica, s. 327.
} 
